\title{
Transporte de explosivos químicos sometidos a procesos de infiltración y evaporación en suelos
}

\author{
Juan P. Gutiérrez*§, Ingrid Y. Padilla**, Luis D. Sánchez* \\ *Faculty of Engineering, Universidad del Valle, Cinara Institute, Cali, Colombia Cali, Colombia \\ **Department of Civil Engineering and Surveying, University of Puerto Rico, Mayagüez, Puerto Rico \\ §Juanpagu@univalle.edu.co
}

(Recibido: Abril 30 de 2010 - Aceptado: Noviembre 23 de 2010)

\begin{abstract}
Resumen
Es necesario conocer el destino y el transporte de Compuestos Explosivos Relacionados (ERCs en inglés) para evaluar la contaminación potencial y para proteger los suministros de agua potable de contaminantes tóxicos, desarrollar estrategias de remediación, y facilitar la detección de explosivos enterrados. En este estudio se desarrollaron seis experimentos para evaluar los efectos de la infiltración y evaporación en el transporte de químicos explosivos. Estos experimentos se realizaron en una columna cilíndrica de $100 \mathrm{~cm}$ de longitud empacada con arena homogénea, instrumentada con sensores de presión de aire y agua y puntos de muestreo para monitorear las condiciones hidráulicas y perfiles de concentración de ERCs en el suelo. Esta investigación estudió el comportamiento del transporte de ERCs en el suelo bajo diferentes condiciones ambientales, cuando se sometieron a la advección (movimiento de fluidos). Los resultados mostraron que el transporte de TNT (2,4,6 trinitrotolueno) y DNT (2,4 dinitrotolueno) está influenciado por la disolución (fuente-agua), la volatilización (agua-aire), y las limitaciones en la transferencia de masa por adsorción (agua-suelo). El movimiento hacia abajo con el agua infiltrada por lo general es retardado por procesos de adsorción en los suelos y superficies de contacto aire-agua. El movimiento ascendente del agua durante la evaporación resultó en el movimiento ascendente de ERCs hacia la superficie sueloatmósfera. La evaporación del agua cerca de la superficie del suelo produjo un aumento de la concentración de ERC cerca de la superficie del suelo después de períodos prolongados de evaporación.
\end{abstract}

Palabras Claves: Infiltración, Evapotranspiración, Advección, Reverso de Flujo, Explosivos.

ENVIRONMENTAL ENGINEERING

\section{Transport of explosive chemicals when subjected to infiltration and evaporation processes in soils}

\begin{abstract}
Knowledge of Explosive Related Compounds (ERCs) fate and transport is necessary to assess contamination potential to protect drinking water supplies from toxic contaminants, develop remediation strategies, and facilitate the detection of buried explosives. In this study six experiments were developed to evaluate the effects of infiltration and evaporation events on explosive chemicals transport. These experiments were conducted in a $100 \mathrm{~cm}$ uniform cylindrical sand column packed with homogeneous sand, instrumented with air and water pressure sensors and sampling ports to monitor hydraulic conditions and ERCs concentration profiles in soil. This research studied the transport behavior of ERC in soil under different environmental conditions, when subject to advection (fluid movement). The results show that transport of TNT (2,4,6 trinitrotoluene) and DNT (2,4 dinitrotoluene) is influenced by dissolution (source-water), volatilization (water-air), and sorption (watersoil) mass transfer limitations. Downward movement with infiltrating water is generally retarded by sorption processes at soil and air-water surfaces. Upward movement of water during evaporation processes results in upward movement of ERCs toward the soil-atmospheric surfaces. Water evaporation near the soil surface results in increased ERCs concentrations near the soil surface after prolonged evaporation periods.
\end{abstract}

Keywords: Infiltration, Evapotranspiration, Advection, Flow Reversal, Explosives. 


\section{Introducción}

The mobility and persistence of ERCs in soils are controlled by fate and transport processes (Figure 1) involving advection, dispersion, mass transfer, and various reactions, Brannon et al. (1999), Comfort et al. (1995). Advective and dispersive processes relate to the movement of the chemicals with and within the bulk fluids (water, air), and control the direction and magnitude of this movement. Chemical, physical, and biological reactive processes influence the fate of the chemicals and overall transport. These processes include sorption, precipitation, and transformations. Mass transfer among available environmental compartments (e.g., water, air, organic matter, air-water interface) could strongly influence the rate at which ERCs move in the soil.

Fate and transport processes are described by parameters which are function of physical, chemical, biological and environmental conditions, depending on movement with air and water, dispersion in air and water sorption, degradation and mass transfer between phases.
The equation (1) describes the interaction of these parameters on mobile phase:

$\frac{\partial}{\partial t}\left(\theta_{m w} C_{m w}+f \rho_{b} C_{s}+A_{a w} C_{a w}+\theta_{g} C_{g}\right)=\frac{\partial}{\partial z}\left(\theta_{m w} D_{m w}^{*} \frac{\partial C_{m w}}{\partial z}+\theta_{g} D_{g}^{*} \frac{\partial C_{g}}{\partial z}\right)$

$\frac{\partial}{\partial z}\left(\theta_{m w} v_{m w}+\theta_{g} v_{g}\right) \pm\left.\sum \frac{\partial \theta_{m w, g} C_{m w, g}}{\partial t}\right|_{r x n} \pm \sum m_{t_{i / j}}$

Where $\mathrm{C}$ is concentration, $\theta$ is the fluid content, $\rho_{\mathrm{b}}$ is the bulk density, $f$ is the fraction of soil in sorption equilibrium with water, $A(\theta)$ is the saturation dependent air-water interfacial area, D* is the total effective dispersion coefficient, $v$ is fluid velocity, $\mathrm{m}$ is mass transfer. The subscripts $m w$, $i m w, s$, $a w$, and $g$ refer to the mobile water, immobile water, solid phase, air-water interface, and gas phase, respectively.

Few experimental researches have been conducted to establish the effect of flow reversal in the fate and transport of explosive chemicals through porous media, (Phelan et al. (2000), Jhorar et al. (2002)). Therefore, it is our goal to evaluate how flow reversal will affect the

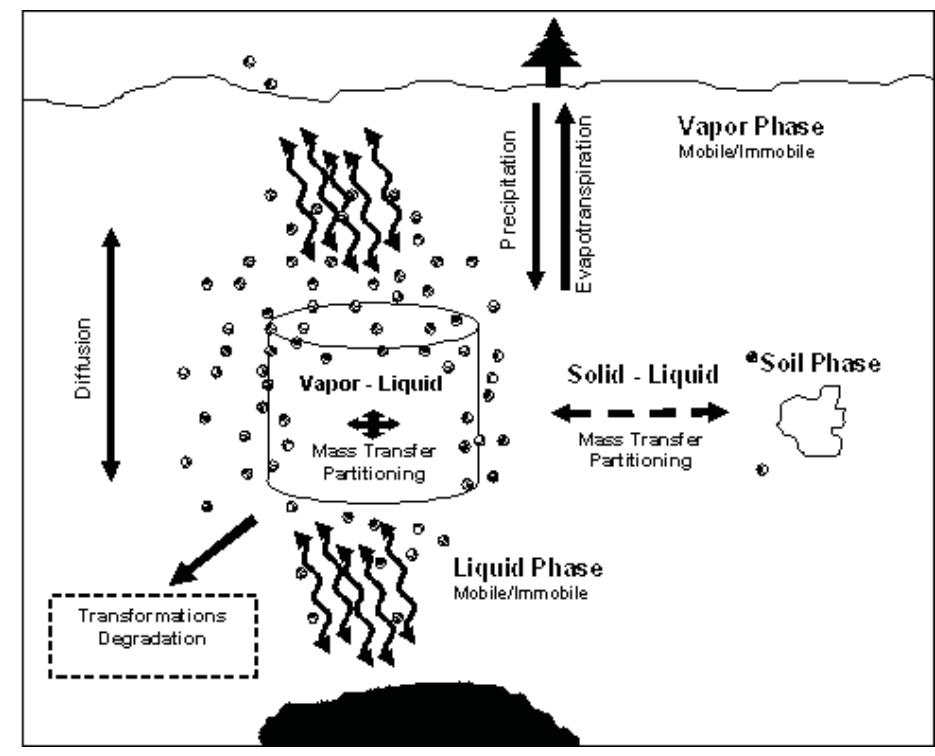

Figure 1. Environmental fate and transport for buried landmines. (Gutiérrez, 2008) 


\section{Material and methods}

A uniform cylindrical column, $100 \mathrm{~cm}$ long and 19 $\mathrm{cm}$ inside diameter, packed with homogeneous sand was built from a stainless steel tube. A total of six (6) experiments were performed under saturated and unsaturated conditions to accomplish the goal of this study.

\subsection{Experimental setup}

The experimental setup consisted of columns initially saturated with a solution-delivery and airsweeping systems, vertically-placed sand columns, and vacuum and waste chambers (Figure 2). The solution delivery system conducted the aqueous solution to the column and consisted of solution reservoirs connected to liquid pump. For saturated conditions the $\mathrm{NaCl}$ solution (prepared based on DI water) delivery pump was comprised of a high pressure liquid chromatography (HPLC) pump connected to the top of the column. For unsaturated conditions the solution was pumped using a peristaltic pump connected through a nozzle to distribute the water over the surface area of the column. This system was only active when infiltration conditions were imposed in the column. The air sweeping system delivered dry air across the soil surface to enhance evaporation. It consisted of an air-sweeping chamber fitted to the top of the column and connected to an air-delivery line on one face and an outlet line on the opposite face (Figure 2). The air-delivery line was connected to the air-outlet of a vacuum. The air was passed first through a moisture trap with Drierite (Anhydrous Calcium Sulfate) packed in a Plexiglas tube in order to remove the moisture contained in air.

The sand columns (Figure 2) consisted of a stainless steel (SS) tube closed at both ends with SS caps. SS porous plates with average pore sizes of 10 and 100 $\mu \mathrm{m}$ and bubbling pressures of 103 and 24 mbars were placed at the bottom and top ends of the columns, respectively, to provide support for the porous media and maintain unsaturated water flux conditions at the bottom and atmospheric conditions at the top.
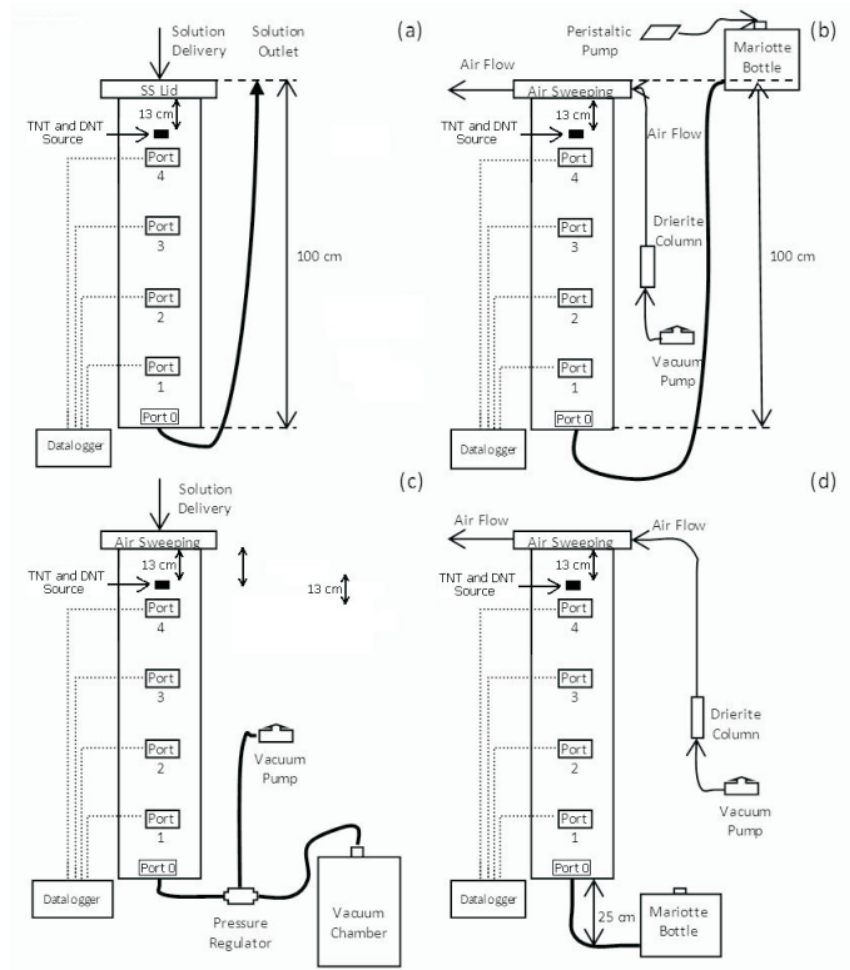

Figure 2. Experimental setup for saturated conditions during infiltration (a) and evaporation (b) events; and for unsaturated conditions during infiltration (c) and evaporation (d) events 
bottom of the column during the entire experiment. The flow rates required to achieve particular saturation $(45,60,75 \%)$ under an imposed constant pressure condition of -24.52 mbar $(-25 \mathrm{~cm}$ of $\mathrm{H} 2 \mathrm{O})$ were determined from flow simulations using HYDRUS 1D, (Šimůnek et al. (2005)).

For saturated experiments, the simulated landmine was buried by initially saturating the column, then lowering the water table to Port 4 ( $22 \mathrm{~cm}$ below the soil surface) before burying the simulated landmine. The water table was thereafter raised to the top again. Once the water table reached the top, infiltration process was started at time zero. For unsaturated experiments, the column is drained to desired average water content by adjusting the flow rate of the $4 \mathrm{mM} \mathrm{NaCl}$ solution and applying a $-25 \mathrm{~cm}$ constant suction at the bottom. When the pressures in the column reached equilibrium, the landmine was inserted without stopping the water flow. The beginning of the experiment (time 0 ) is considered to be at the time the source is completely buried.

Transport experiment started by imposing infiltration events initially, followed by evaporation events. Infiltration conditions were imposed by injecting a $20 \mathrm{mM} \mathrm{NaCl}$ tracer solution at the top of the column until the $\mathrm{NaCl}$ front reached the bottom of the column (Port 0). Evaporation conditions were imposed after infiltration periods by discontinuing the delivery of the infiltrating solution, and passing dry air through the air-sweeping system on top of the column (Figure 2). Under saturated conditions, a constant head was maintained at the top of the column to replenish the evaporated water. The infiltrating solution was set at $20 \mathrm{mM}$ for displacement of resident background water and set back to background solution ( $4 \mathrm{mM}$ ) thereafter for elution of the initially infiltrated $20 \mathrm{mM}$ solution. This was done to conduct a complete miscible displacement breakthrough curve (BTC) during infiltration periods and better characterize advective and dispersive processes. For all experiments, a $20 \mathrm{mM}$ solution was set as the evaporation replenishment source. Under unsaturated conditions, a constant tension head was maintained at the bottom of the column to replenish the evaporated water. The effect of 20
$\mathrm{mM} \mathrm{NaCl}$ solution on the fate and transport processes of ERCs is considered negligible. Brannon et al. (2005) studied the influence of salt concentration in dissolution, sorption and transformation rates of some ERCs as TNT, RDX and HMX. They concluded that even thought high $\mathrm{NaCl}$ concentration can decrease the explosives dissolution rates it is considered neglected. The salt concentration used during their experiments was $20 \mathrm{ppt}$, therefore the differences in dissolution rates expected for these experiments are neglected considering that the changes in the solution injected were about $0.1 \mathrm{ppt}$.

Aqueous and vapor samples were collected temporally and spatially during the experiments. The concentration was plotted vs. time to establish BTC at each sampling point. The BTC was then analyzed using moments analysis and numerical models as described below.

Spatial and temporal concentrations of $\mathrm{NaCl}$, TNT, and DNT in the soil water and air (only ERCs vapors) phases, were estimated by analyzing water and vapor samples taken from samplers and outlet ports in the soil column system. $\mathrm{NaCl}$ concentrations were analyzed using conductivity detectors, whereas ERC solutes and vapors were analyzed using gas chromatography techniques. TNT and DNT concentrations were analyzed using various extraction methods and gas chromatography (GC) techniques. ERC analytes were extracted from aqueous samples through liquid-liquid extractions. Liquid-liquid extraction involves the use of isoamyl acetate as the extractions solvent. Extractions were done at a 1:2 sample/solvent ratio by mixing for 15 minutes, followed by a separation period of 5 minutes. Once extracted, the ERC in the extract was analyzed in a GC (Model CP-3800, Varian Inc) equipped with an electron capture detector (ECD) and a thermionic specific detector (TSD). As the concentrations were variable ranging from $\mu \mathrm{g} / \mathrm{L}$ to $\mathrm{mg} / \mathrm{L}$ it was necessary to use both detectors at different sensitivities, setting in all cases the injector temperature at $250^{\circ} \mathrm{C}$. Explosive concentrations were determined using liquidliquid extraction calibration curves.

After withdrawing gas samples, vapor samples were extracted by inserting a SPME fiber 
The column used contained sampling port clusters located at 19.5 (Port 1), 39.0 (Port 2), 58.5 (Port 3), and $78.0 \mathrm{~cm}$ (Port 4) from the bottom (Port 0), in which were located a water pressure sampler, a liquid sampler, a gas pressure sampler, and a gasphase sampler. The liquid and vapor samplers were used to measure the spatial and temporal concentration distribution of ERCs and other chemicals in the water and gas phases. Pressure samplers were used to monitor soil-water content and pressures and soil-gas pressure, and determine flow conditions. The samplers consisted of stainless steel porous cups to selectively sample the water or the gas phases in the soil, (Padilla et al. (2006)).

The column was packed with beach sand from Isabela, Puerto Rico. This sand consists mainly of quartz and calcite, poorly graded, with a 2.83 $\mathrm{g} / \mathrm{cm}^{3}$ specific gravity and a $1.687 \mathrm{~m}^{2} / \mathrm{g}$ specific surface area, (Molina et al. (2006)). Isabela sand is primarily composed of $92.6 \%$ sand sizes, and $7.4 \%$ of fines (silts and clays). The sand was packed in the stainless steel column following a procedure developed by Rodríguez et al. (2006) to achieve consistent and reproducible bulk densities and soil porosities. The sand was packed to a bulk density of $1.65 \mathrm{~g} / \mathrm{cm}^{3}$ and a media porosity of $41 \%$. These values are within acceptable bulk density and porosity range for natural sandy soils (Fetter, 1999; Phelan \& Webb, 1998).

\subsection{Transport experiments and data analysis}

Transport experiments (Table 1) involved introducing a TNT/DNT point source below the soil surface, and inducing infiltration and evaporation events, while monitoring chemical concentrations in the aqueous and gaseous phases. TNT $(2,4,6$ trinitrotoluene) $(30 \%$ minimum water) and DNT (2,4 dinitrotoluene) crystals with a purity $>99 \%$ were purchased from Chem Service (West Chester, PA), whereas TNT and DNT standard solutions (concentration in acetonitrile) were from the Restek corp (Bellefonte, PA). A total of six (6) experiments were conducted under different water content, flow, and temperature conditions (Table 1). TNT and DNT crystals (180 $\mathrm{mg}$ of each one) were placed in a nylon bag (pore size $\sim 49 \mu \mathrm{m}$ ), simulating a landmine point source. The source was buried at the center of the column, $13 \mathrm{~cm}$ from the soil surface ( $9 \mathrm{~cm}$ above Port 4$)$.

The experiments were conducted at different water contents and temperature conditions (Table 1). Four column-averaged water contents $(45,60$, 75 and $100 \%$ saturation) were used at a $25^{\circ} \mathrm{C}$ constant temperature. Two column-averaged water contents (60 and 100\% saturation) were used at $35^{\circ} \mathrm{C}$. Unsaturated water contents were achieved by varying the flow rate at the top of the column during infiltrating periods, while maintaining a $-25 \mathrm{~cm}$ constant suction head at the

Table 1. Description of experimen tal conditions

\begin{tabular}{|c|c|c|c|c|c|}
\hline \multirow{3}{*}{$\begin{array}{l}\text { Experiment } \\
\text { Number }\end{array}$} & \multirow{3}{*}{$\begin{array}{c}\text { Temperature } \\
\left({ }^{\circ} \mathrm{C}\right)\end{array}$} & \multirow{3}{*}{$\begin{array}{c}\text { Degree of } \\
\text { Saturation (\%) }\end{array}$} & \multicolumn{3}{|c|}{ Flow Regime } \\
\hline & & & \multicolumn{2}{|c|}{ Infiltration $^{(1)}$} & \multirow{2}{*}{$\begin{array}{l}\text { Evaporation } \\
\text { Period (min) }\end{array}$} \\
\hline & & & Rate $(\mathrm{cm} / \mathrm{min})$ & Period (min) & \\
\hline 1 & 25 & 100 & 0.007 & 3,150 & 84,270 \\
\hline 2 & 25 & 75 & 0.071 & 1,004 & 74,536 \\
\hline 3 & 25 & 45 & 0.007 & 7,080 & 44,360 \\
\hline $4^{(2)}$ & 35 & 100 & 0.007 & 27,300 & 99,740 \\
\hline 5 & 25 & 60 & 0.035 & 7,320 & 64,880 \\
\hline 6 & 35 & 60 & 0.035 & 7,380 & 64,880 \\
\hline
\end{tabular}

${ }^{(1)}$ Infiltration Rate $(\mathrm{cm} / \mathrm{min})=\mathrm{Q} / \mathrm{A}$, where $\mathrm{A}=283.4 \mathrm{~cm}^{2}$

${ }^{(2)}$ Experiment 4 consisted of 2 saturated infiltration/evaporation cycles 
Polydimethysiloxane/divinylbenzene $(65 \mu \mathrm{m}$ film coating from Supelco) into the sampler for 4 minutes. The sampling time was decided considering the results obtained in other studies (Torres et al., 2007) who determined that a time of 4 minutes was adequate to detect DNT and TNT concentrations as low as $\mathrm{ng} / \mathrm{L}$. The samples were analyzed with a SRI $8610 \mathrm{C}$ Gas Chromatograph equipped with a micro electron capture detector and a $0.25 \mathrm{~mm}$ x $15 \mathrm{~m}$ RTX XLB column (Restek). Explosive concentrations were determined using SPME calibration curves.

The transport experiments generated spatial and temporal pressure and concentration data. Spatial and temporal concentration breakthroughs were analyzed comparatively and analytically to determine transport behavior of solutes and ERCs under the imposed conditions. Analytical assessment involved using the Method of Moments (MOM) for temporal concentration distribution.

The MOM for temporal concentration distributions was used to characterize the $\mathrm{NaCl}$ breakthrough data (Gutiérrez, 2008). Experimental absolute moments, $\mathrm{M}_{\mathrm{n}}$, are obtained through numerical integration of the breakthrough data (Eq. 2) using the trapezoidal rule (Padilla et al., 1999).

$$
M_{n}=\int_{0}^{\infty} t^{n} C(z, t) d t
$$

Where $\mathrm{C}$ is the solute concentration, $\mathrm{z}$ is the spatial coordinate and $t$ is the time.

Using this method, the zero $\left(\mathrm{M}_{0}\right)$ and first $\left(\mathrm{M}_{1}\right)$ moments are calculated as (Eq. 3 and 4 ):

$$
\begin{aligned}
& M_{0}=\int_{0}^{\infty} C(z, t) d t=\sum\left(\frac{C_{i}+C_{i+1}}{2}\right)\left(t_{i+1}-t\right) \\
& M_{1}=\int_{0}^{\infty} t C(z, t) d t=\sum\left(\frac{C_{i} t_{1}+C_{i+1} t_{i+1}}{2}\right)\left(t_{i+1}-t\right)
\end{aligned}
$$

The first normalized absolute moment of the input pulse and the effluent concentration signal are used to estimate the mean arrival time of the center

$$
\mu=\frac{M_{l}^{I I}}{M_{0}^{I I}}-\frac{M_{l}^{I}}{M_{0}^{I}}
$$

where the I and II superscripts refer to the moments of the input and output signals, respectively. The mean arrival time is used in conjunction with the column length $\mathrm{L}$ to calculate the pore water velocity $(v=L / \mu)$. An effective water content $\theta_{\mathrm{e}}$ is estimated from the Darcy flux divided by the moment-derived pore water velocity (Eq. 6) (Padilla et al., 1999).

$$
\theta_{e}=\frac{Q}{A \cdot v}
$$

\section{Results and discussion}

Results indicate that TNT and DNT transport is highly influenced by these conditions and events. When subjected to periods of infiltration and evaporation, the principal component of water flux can be downward, stagnant, or upward. Hydraulic and $\mathrm{NaCl}$ concentration measurements indicate that water flow is principally downward during infiltration events (Figures 3 and 4). After infiltration periods, water flux may be principally downward, stagnant and/or upward.

The existence of hydraulic heterogeneities and preferential flow paths in saturated and unsaturated media during the events of infiltration is clear in the estimates of water content and $\mathrm{NaCl}$ temporal distributions (Table 2). During the burial of ERCs is disturbed the soil producing preferential flow paths near the surface of infiltration, as evidenced by the differences in travel times (Table 2). Water contents in unsaturated flow decreased with depth at ambient temperature $\left(25^{\circ} \mathrm{C}\right)$ during periods of infiltration, but increased with depth at higher temperatures $\left(35^{\circ} \mathrm{C}\right)$ (Table 2$)$. The increased water content with depth at higher temperatures is attributed to the water drainage of the upper portions of soil in lower regions. This drain is caused by the decrease of soil water stress, due to lower surface tension of water and higher air-water contact angles of sand. Variations in water content with depth modify the hydraulic properties and can induce preferential 

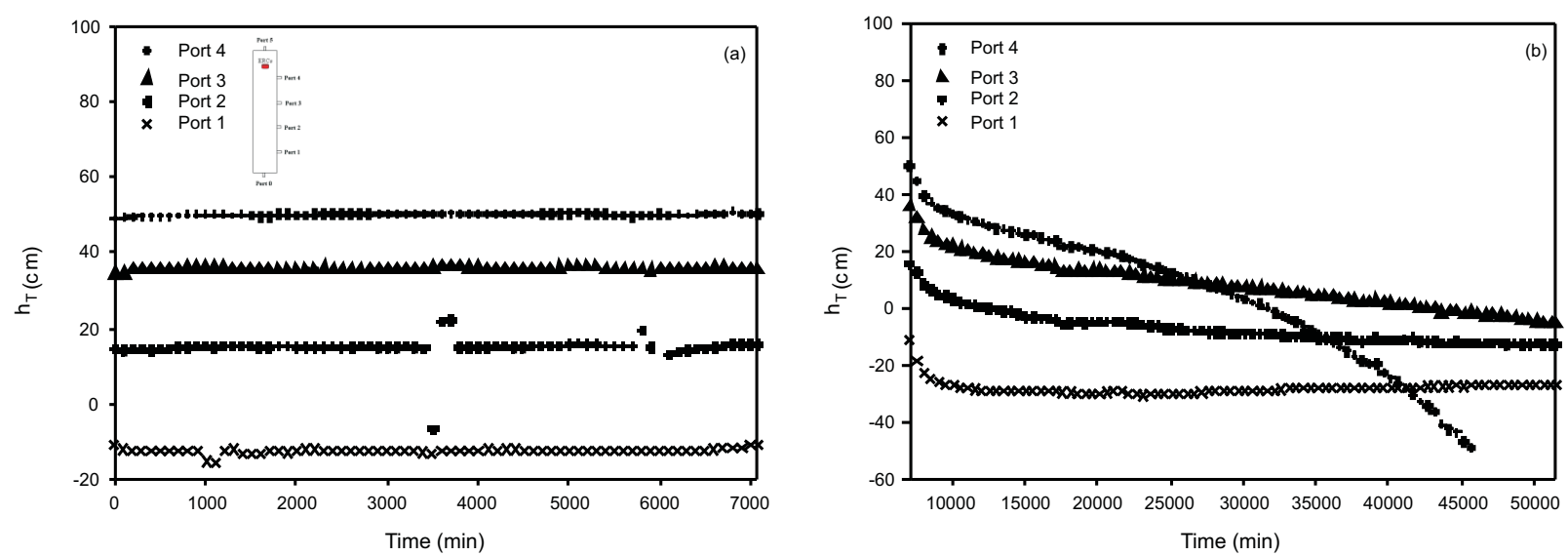

Figure 3. Total hydraulic heads during infiltration (a) and evaporation (b) processes under $45 \%$ of saturation at 25 ${ }^{\circ} \mathrm{C}$ (Exp 3)
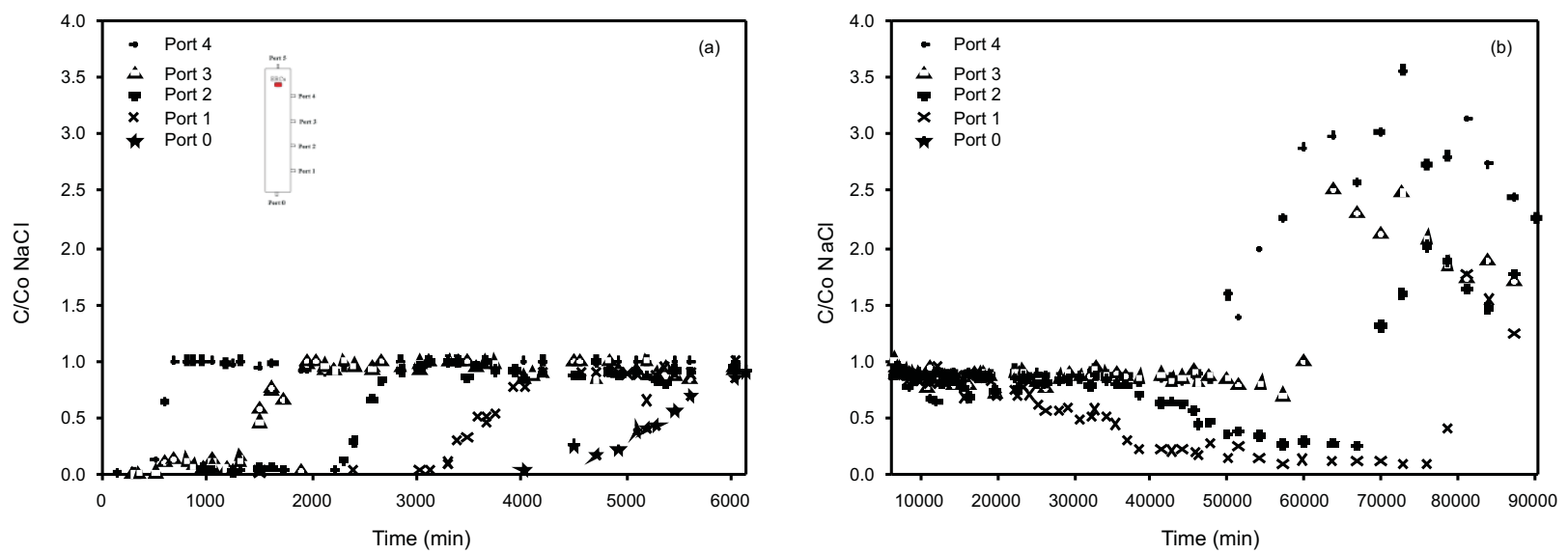

Figure 4. NaCl breakthrough curves during infiltration (a) and evaporation (b) processes under saturated conditions at $25^{\circ} \mathrm{C}$ (Exp 1)

During infiltration events were estimated pore water velocities by using the MOM. Results suggest greater velocities, thus lower effective water contents, closest to the soil surface (port 4) than the other ports for all experiments, less for experiment 5 (Table 2). Lower effective water content estimates than saturated porosity $(\mathrm{n}=0.34$ 0.41 ), suggest that the entire volume is not participating in flow processes and that preferential flow exists in the system under saturated conditions.

Pore water velocities are not significantly different for experiments conducted at $25^{\circ} \mathrm{C}$ and $35^{\circ} \mathrm{C}$. Velocity differences are expected at different temperatures because of the temperature dependency of the water density $\left(\rho_{w}\right)$ and dynamic viscosity $\left(\mu_{\mathrm{w}}\right)$. Based on variations in $\rho_{\mathrm{w}}$ and $\mu_{\mathrm{w}}$ with temperature, saturated hydraulic conductivities at $35^{\circ} \mathrm{C}\left(\mathrm{K}_{\mathrm{s}\left(35^{\circ} \mathrm{C}\right)}\right)$ can be estimated from values at $25^{\circ} \mathrm{C}$ as:

$K_{s\left(35^{0} \mathrm{C}\right)}=K_{s\left(25^{\circ} \mathrm{C}\right)} \frac{\rho_{w, 25^{0} \mathrm{C}}}{\mu_{w, 25^{\circ} \mathrm{C}}} \frac{\mu_{w, 35^{0} \mathrm{C}}}{\rho_{w, 35^{\circ} \mathrm{C}}}=K_{s\left(25^{0} \mathrm{C}\right)} \times 1.2$

Where $\rho_{\mathrm{w}}$ and $\mu_{\mathrm{w}}$ values are given by Roberson \& Crowe (1990). Based on this relationship, the hydraulic conductivity values at $35^{\circ} \mathrm{C}$ are expected to be slightly (1.2 times) greater than those at $25^{\circ} \mathrm{C}$. Comparison of water velocities for saturated experiments (Table 2) shows no observable difference between the two. For the unsaturated 
Table 2. Parameters obtained from $\mathrm{NaCl}$ BTCs using the MOM during infiltration process

\begin{tabular}{|c|c|c|c|c|c|c|c|}
\hline \multirow[b]{2}{*}{ Experiment } & \multirow[b]{2}{*}{$\begin{array}{l}\text { Front } \\
\text { Elution }\end{array}$} & \multicolumn{6}{|c|}{ Parameter } \\
\hline & & $\begin{array}{l}\text { Mean Arrival } \\
\text { Time ( } \mu, \text { min) }\end{array}$ & $\begin{array}{c}\text { Pore Water } \\
\text { Velocity (v, } \\
\mathrm{cm} / \mathrm{min})\end{array}$ & $\begin{array}{c}\text { Effective } \\
\text { Water Content } \\
\left(\theta_{\mathrm{e}}, \%\right) \\
\end{array}$ & $\begin{array}{c}\text { Total Mass } \\
\text { Measured } \\
(\mathrm{mg}) \\
\end{array}$ & $\begin{array}{l}\text { Theoretical } \\
\text { Mass (mg) }\end{array}$ & $\begin{array}{c}\text { Mass Ratio } \\
\text { (Measured/Theor) }\end{array}$ \\
\hline \multirow{5}{*}{1} & Port 4 & 336.57 & 0.07 & 10.79 & 798.15 & 655.95 & 1.22 \\
\hline & Port 3 & 894.20 & 0.05 & 15.20 & 2189.86 & 1237.35 & 1.77 \\
\hline & Port 2 & 1587.27 & 0.04 & 18.36 & 3183.70 & 1818.76 & 1.75 \\
\hline & Port 1 & 2332.82 & 0.03 & 20.44 & 4578.31 & 2400.17 & 1.91 \\
\hline & Port 0 & 4331.19 & 0.02 & 30.55 & 5067.75 & 2981.58 & 1.70 \\
\hline \multirow{5}{*}{2} & Port 4 & 32.38 & 0.68 & 10.38 & 990.41 & 617.63 & 1.60 \\
\hline & Port 3 & 67.43 & 0.62 & 11.46 & 2327.16 & 1165.08 & 2.00 \\
\hline & Port 2 & 100.8 & 0.61 & 11.66 & 3413.45 & 1712.53 & 1.99 \\
\hline & Port 1 & 112.56 & 0.72 & 9.86 & 3868.49 & 2259.97 & 1.71 \\
\hline & Port 0 & 425.24 & 0.24 & 30.0 & 4462.34 & 2807.42 & 1.59 \\
\hline \multirow{5}{*}{3} & Port 4 & 171.03 & 0.13 & 5.48 & 502.51 & 634.49 & 0.79 \\
\hline & Port 3 & 420.17 & 0.10 & 7.14 & 1337.4 & 1196.88 & 1.12 \\
\hline & Port 2 & 550.87 & 0.11 & 6.37 & 1647.3 & 1759.27 & 0.94 \\
\hline & Port 1 & 676.57 & 0.12 & 5.93 & 2129.45 & 2321.66 & 0.92 \\
\hline & Port 0 & 1208.26 & 0.08 & 8.52 & 3600.49 & 2884.05 & 1.25 \\
\hline \multirow{5}{*}{4} & Port 4 & 680.66 & 0.03 & 11.19 & 983.68 & 659.01 & 1.49 \\
\hline & Port 3 & 1177.70 & 0.04 & 10.26 & 1812.16 & 1243.14 & 1.46 \\
\hline & Port 2 & 1908.08 & 0.03 & 11.31 & 3032.77 & 1827.26 & 1.66 \\
\hline & Port 1 & 2915.48 & 0.03 & 13.09 & 4759.93 & 2411.39 & 1.97 \\
\hline & Port 0 & 4235.78 & 0.02 & 15.31 & 7057.26 & 2995.51 & 2.36 \\
\hline \multirow{5}{*}{5} & Port 4 & 239.76 & 0.09 & 38.44 & 1018.53 & 613.03 & 1.66 \\
\hline & Port 3 & 189.63 & 0.22 & 16.12 & 1540.31 & 1156.41 & 1.33 \\
\hline & Port 2 & 188.39 & 0.32 & 10.89 & 2451.49 & 1699.78 & 1.44 \\
\hline & Port 1 & 222.06 & 0.36 & 9.73 & 3633.94 & 2243.15 & 1.62 \\
\hline & Port 0 & 325.48 & 0.31 & 11.48 & 5554.15 & 2786.52 & 1.99 \\
\hline \multirow{5}{*}{6} & Port 4 & 42.40 & 0.52 & 6.80 & 747.37 & 613.03 & 1.22 \\
\hline & Port 3 & 89.31 & 0.46 & 7.59 & 1562.97 & 1156.41 & 1.35 \\
\hline & Port 2 & 166.23 & 0.37 & 9.61 & 2807.63 & 1699.78 & 1.65 \\
\hline & Port 1 & 214.66 & 0.38 & 9.41 & 3797.22 & 2243.15 & 1.69 \\
\hline & Port 0 & 367.86 & 0.27 & 12.97 & 6036.85 & 2786.52 & 2.17 \\
\hline
\end{tabular}


(Table 2), the water velocities at $35^{\circ} \mathrm{C}$ are slightly higher ( $\sim 1.5$ times $)$ than those at $25^{\circ} \mathrm{C}$. The higher velocities can result from $\rho_{\mathrm{w}}$ and $\mu_{\mathrm{w}}$ temperaturedependence and from differences in saturationdependent hydraulic conductivities for unsaturated flow. Slightly different pore water velocities for higher temperature in the unsaturated medium may also result from changes in pressure heads and gradients.

Soil-water pressure measurements, total hydraulic heads (Figure 3), and water content estimates (Table 2) indicate that after an infiltration event, water flux is initially downward, depending on soil depth, water content, and temperature (Gutiérrez, 2008). Soils with higher water contents and higher temperature at the end of the infiltration period show higher degree of drainage (Table 2). Drainage water redistribution was generally followed by a stagnant water flux period during infiltration-evaporation transition in the flux components. This corresponds to a period in which downward drainage redistribution and upward evaporation processes are balanced. Similar to the period following infiltration events, pressure and hydraulic head measurements indicate that the transition period depends on the initial water contents after infiltration, temperature, and depth. The transition is seen initially in the upper ports, and starts earlier for soils with higher initial water contents. The infiltration-evaporation transition period is, however, slower (takes longer) for the higher initial water content soils. After this transition period, evaporation pressures at the surface of the soil controls water flux causing it to be predominantly upward. Evaporate-fluxes toward the end of the experiments are generally higher than infiltration periods under the same conditions (Table 3).

TNT and DNT BTCs indicate downward movement with infiltrating water. The infiltrating concentrations are, however, controlled by ratelimited dissolution of the ERC source, preferential flow, and incomplete mixing of the solutes. Lower TNT and DNT aqueous concentrations than their solubility values $(127.240 \mathrm{mg} / \mathrm{L}$ and 199.056 $\mathrm{mg} / \mathrm{L}$ at $25^{\circ} \mathrm{C}$ for TNT and DNT, respectively) (Phelan and Barnett, 2001) indicate that dissolution of the ERC sources is rate limited.
Higher aqueous concentrations at higher water contents suggest that dissolution kinetics is dependent on water-flux (Figures 5 through 7). At higher water content are observed higher aqueous TNT and DNT concentrations, however the transport is limited which is evidenced in Figure 7, presenting higher concentrations in the upper layers. At lower water content are observed lower aqueous concentrations, even it is enhanced the solute transport obtaining higher aqueous concentrations in the lower layers (Figures 5 and 6). This behavior is observed in the concentrations obtained in the lower sampling ports, approaching to a limit concentration at the lower water content (Figure 5) after 3,000 minutes approximately where the behavior of the concentration is stabilized and has a tendency to become independent of time. At higher water contents is not observed such behavior.

The downward movement of TNT and DNT with infiltrating water is generally retarded (moves slower) with respect to water (or conservative tracers), indicating sorption of ERC onto the soil and other surfaces present in the system (Figure 8). For unsaturated conditions, air-water interfaces can potentially act as sorption surface (Hoff et al., 1993; Costanza \& Brusseau, 2002). Because air-water interfacial areas vary with water content, TNT and DNT sorption at the airwater interface would vary with water content distribution. Variable depth-dependent retardation of TNT and DNT suggest rate-limited sorption, variable sorption capacity, and/or non-linear sorption. Rate-limited sorption may result from preferential flow (Johnson et al., 2002). Variable sorption capacity may occur as water content and interfacial areas distribution vary with depth. Nonlinear sorption would occur if sorption capacity varies with solute concentration. Also, color changes at the surface of the soil after experiments were observed suggesting TNT/DNT degradation in the soil, which is observed also in the chromatograms obtained by using Gas Chromatography (Gutiérrez, 2008). Unidentified chromatographic peaks indicate the presence of potential degradation products. Since degradation/transformation is an important factor that may affect the fate and transport of ERCs in soils, and appears to be depth-dependent, further studies would have to be made to discern the 
Table 3. Water flux from toward the end of evaporation event

\begin{tabular}{|c|c|c|c|c|c|c|c|}
\hline \multirow{2}{*}{ Experiment } & \multicolumn{2}{|c|}{$\mathbf{P}(\mathrm{cm})$} & \multirow{2}{*}{$\mathrm{dh} / \mathrm{dL}$} & \multicolumn{2}{|c|}{ K(h) $(\mathrm{cm} / \mathrm{min})$} & \multirow{2}{*}{$\begin{array}{c}\text { K(h) average } \\
(\mathrm{cm} / \mathrm{min})\end{array}$} & \multirow{2}{*}{$q(\mathrm{~cm} / \mathrm{min})$} \\
\hline & Port 4 & Port 3 & & Port 4 & Port 3 & & \\
\hline $1^{(1)}$ & & & & & & & 0.022 \\
\hline 2 & -90.89 & -48.98 & 2.149 & 0.018 & 0.063 & 0.041 & 0.087 \\
\hline 3 & -128.60 & -60.53 & 3.491 & 0.008 & 0.043 & 0.025 & 0.089 \\
\hline $4^{(1)}$ & & & & & & & 0.034 \\
\hline 5 & -129.00 & -62.40 & 3.415 & 0.008 & 0.040 & 0.024 & 0.082 \\
\hline 6 & -49.13 & -38.17 & 0.562 & 0.063 & 0.094 & 0.079 & 0.044 \\
\hline
\end{tabular}

${ }^{(1)}$ Water fluxes were calculated from replenishment volumes in the Mariotte's bottle
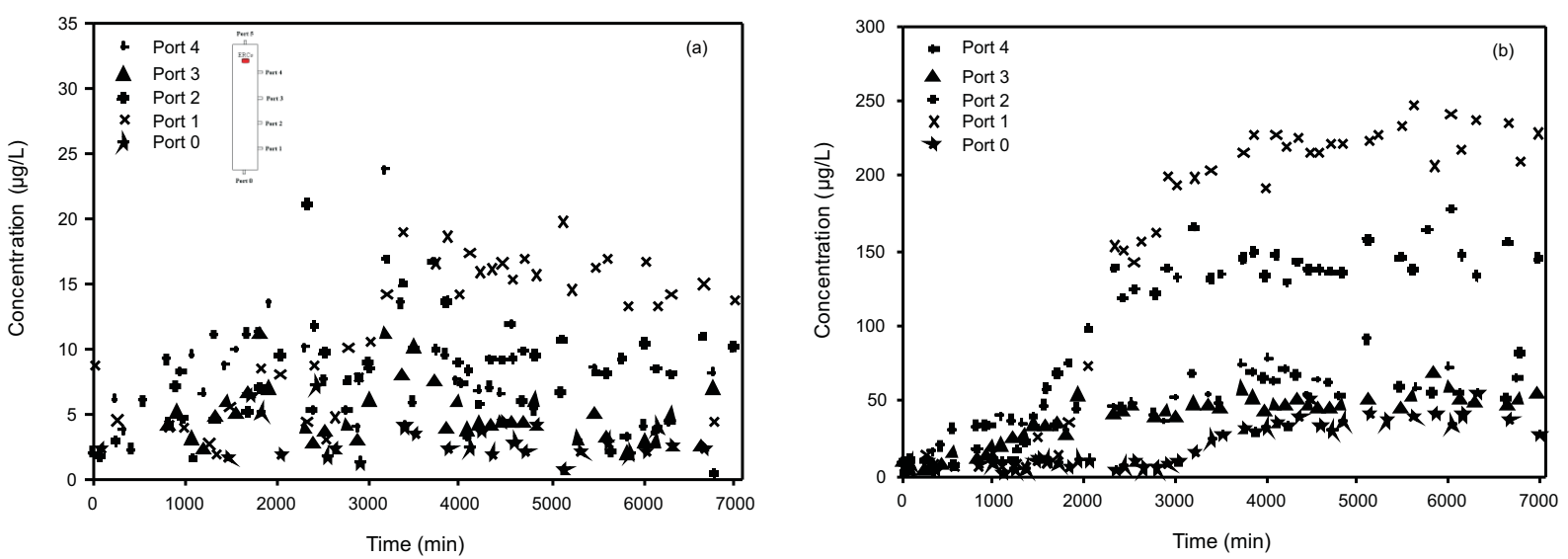

Figure 5. $T N T_{W}$ (a) and $D N T_{W}$ (b) breakthrough curves during infiltration process under $45 \%$ of saturation at $25^{\circ} \mathrm{C}$ (Exp 3)
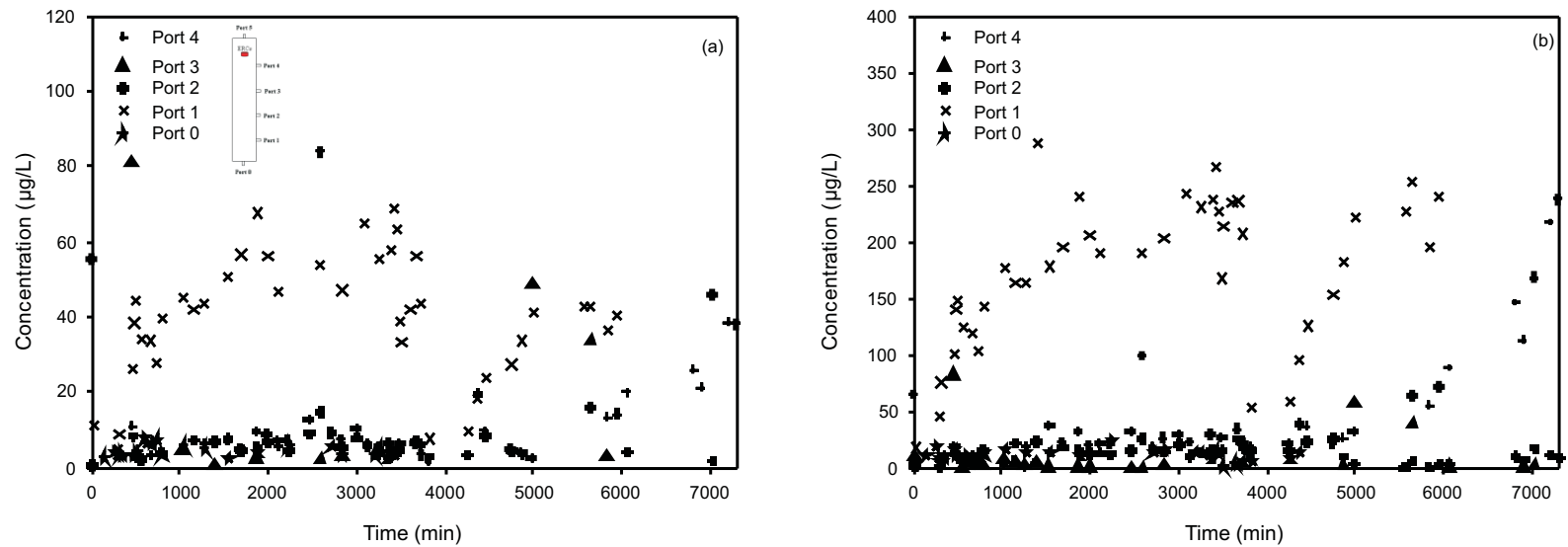

Figure 6. $T N T_{W}$ (a) and $D N T_{W}$ (b) breakthrough curves during infiltration process under $60 \%$ of saturation at $25^{\circ} \mathrm{C}$ (Exp 5) 

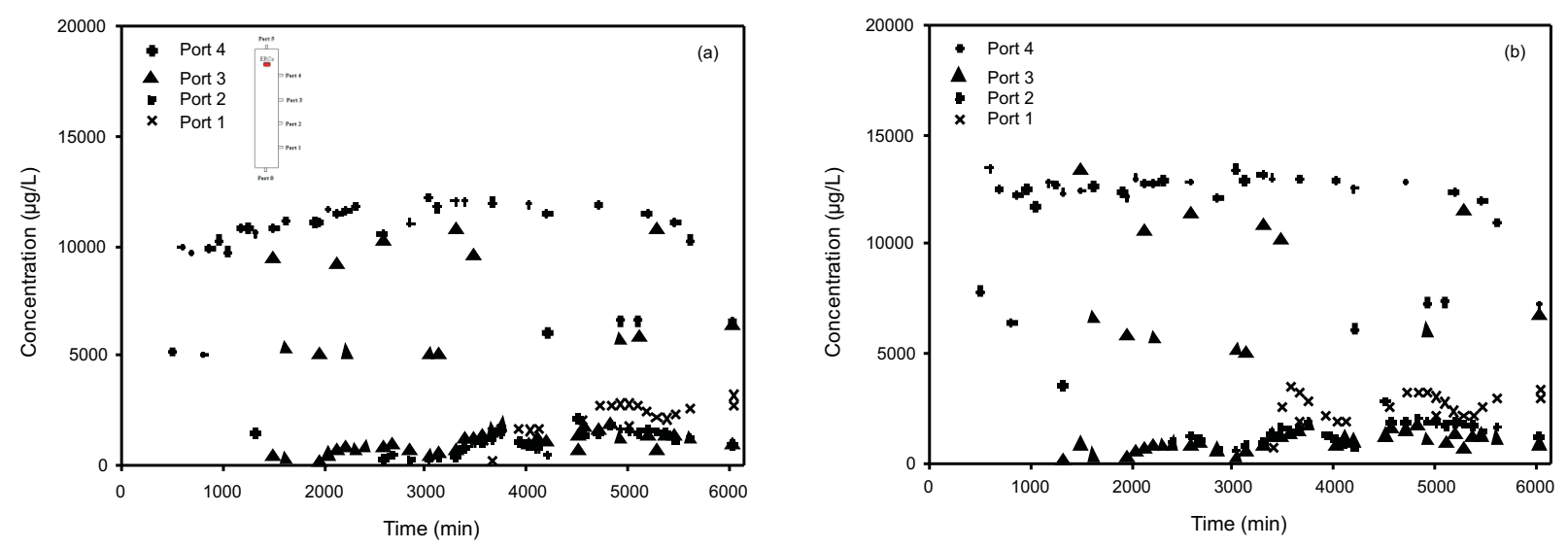

Figure 7. $T N T_{W}(a)$ and $D N T_{W}$ (b) breakthrough curves during infiltration process under saturated conditions at $25^{\circ} \mathrm{C}(\operatorname{Exp} 1)$
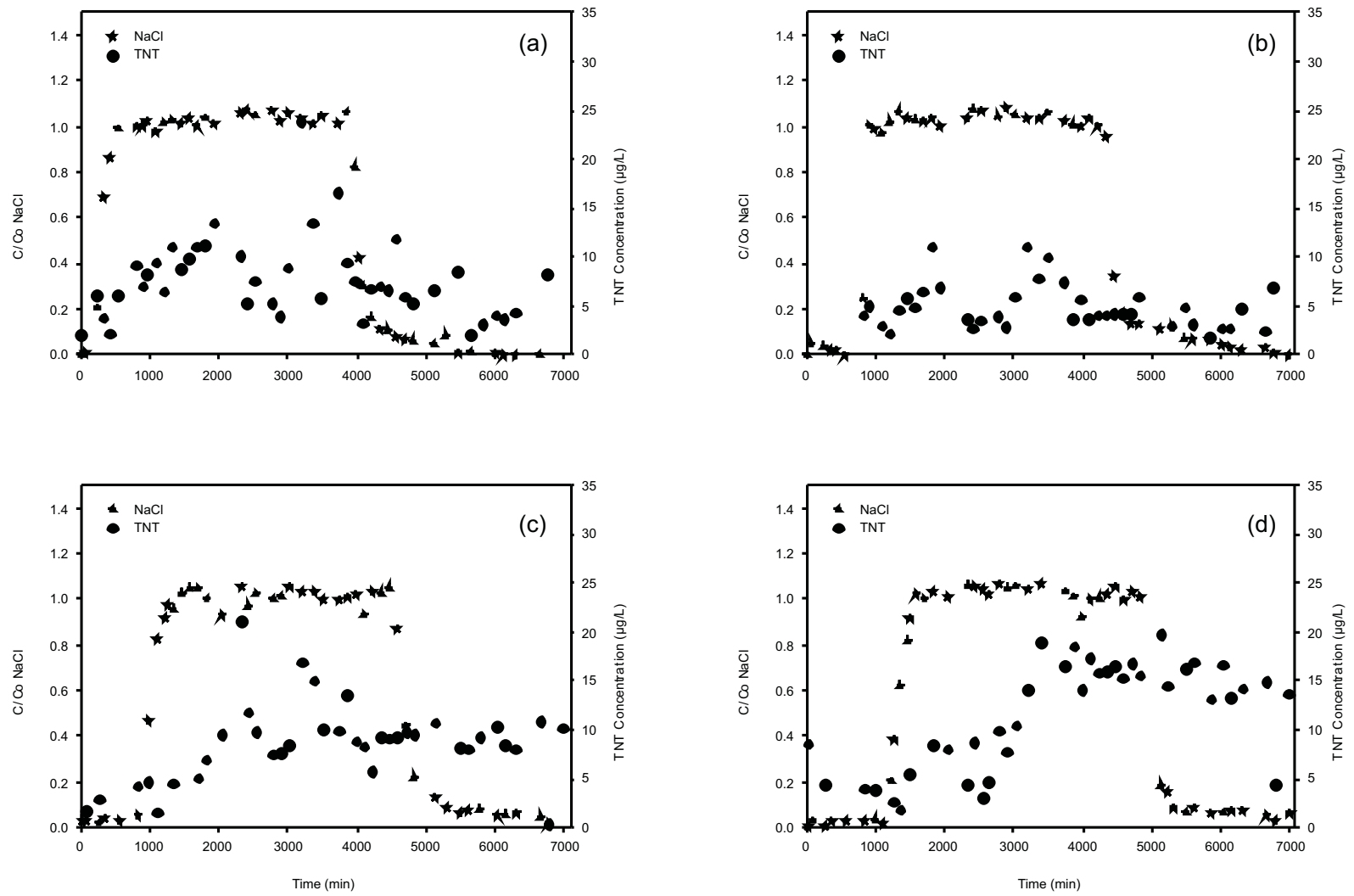

Figure 8. NaCl vs. TNT $T_{W}$ during infiltration process for Port 4 (a), Port 3 (b), Port 2 (c) and Port 1 (d), under $45 \%$ of saturation at $25^{\circ} \mathrm{C}(\operatorname{Exp} 3)$ 
mechanistic processes inducing the observed depth-dependent retardation.

TNT and DNT concentrations during evaporation periods in saturated and unsaturated conditions tend to decrease with time to an asymptotic value (Figure 9). For unsaturated conditions, during evaporation period only the bottom ports were possible to sample due to drainage of the upper sections of the soil. Lower temporal concentrations are attributed to drainage losses during flow redistribution and volatilization loses to the soil-gas and apparently transformation/degradation processes (Figures 9 through 11). Lower concentrations are also attributed to slower diffusion-controlled transport from the TNT/DNT source and potential dilution with evaporation replenishment water. Later upward movement of water during evaporation processes results in upward movement of solutes toward the soil-atmospheric surfaces. Water evaporation near the soil surface result in increased solute concentrations near the soil surface after prolonged evaporation periods (Figure 9).
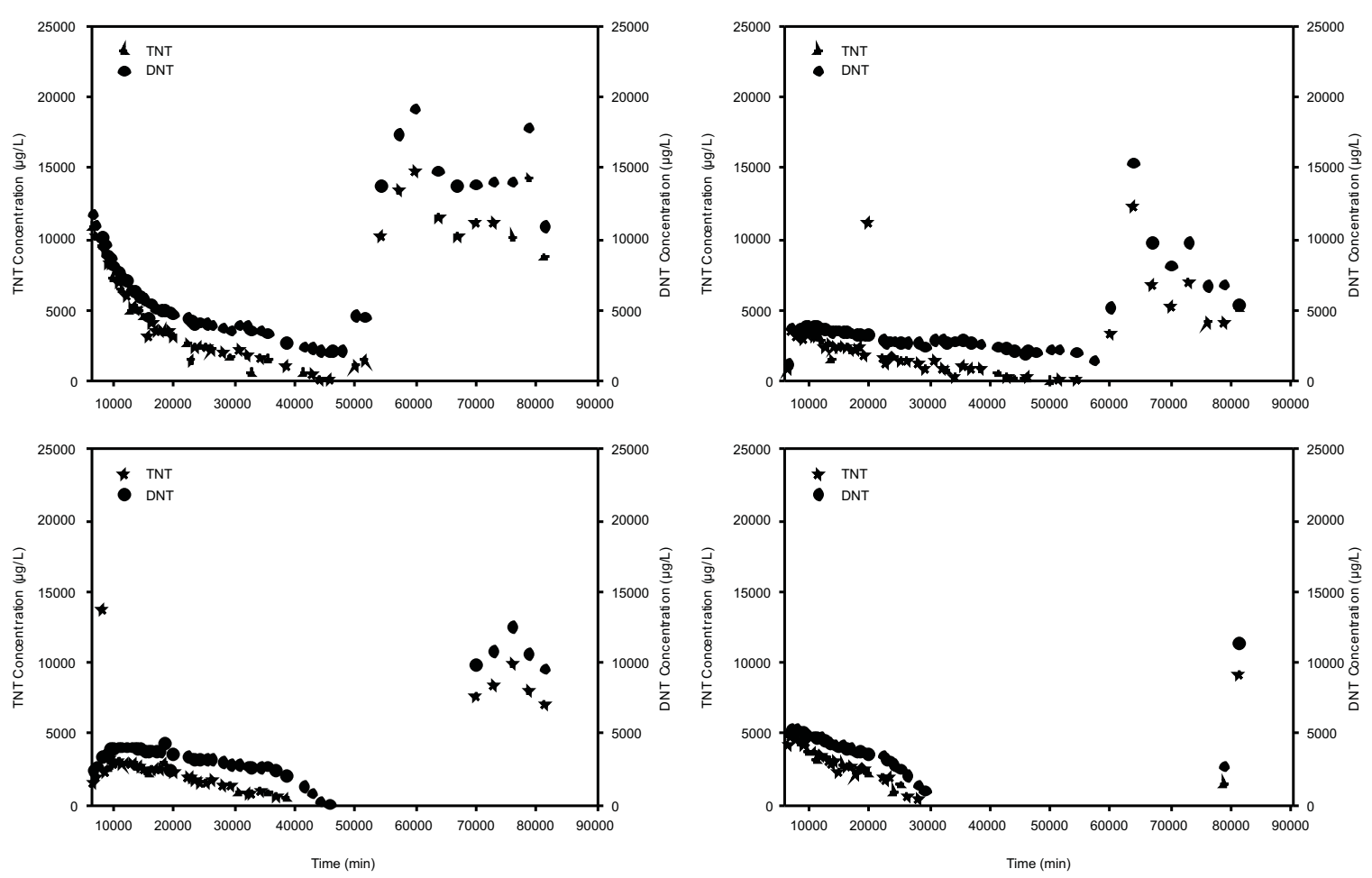

Figure 9. $T N T_{W}$ vs. $D N T_{W}$ during evaporation process for Port 4 (a), Port 3 (b), Port 2 (c) and Port 1 (d),

under saturated conditions at $25^{\circ} \mathrm{C}$ (Exp 1)

Variable TNT and DNT aqueous concentration with time after infiltration periods indicate that their fate and transport is influenced by water redistribution, upward movement of solute-free water during evaporation, and solute accumulation caused by water evaporation at the soil surface. Volatilization loses are reflected in TNT and DNT vapor concentrations throughout the soil and above the soil-atmospheric surface (Figures 10 and 11).

High variability of TNT and DNT vapors indicate variable volatilization and gas-diffusion rates depending on water content and flow conditions. Vapor-phase concentrations during infiltration experiments indicate some upward gaseous movement controlled by gas-phase diffusion and solute volatilization. TNT and DNT vapor-phase concentrations are related to solute concentration in the aqueous phase, thus it is higher for higher water contents at a given temperature. This behavior indicates that volatilization from water controls the gas-phase concentration and fluxes. 

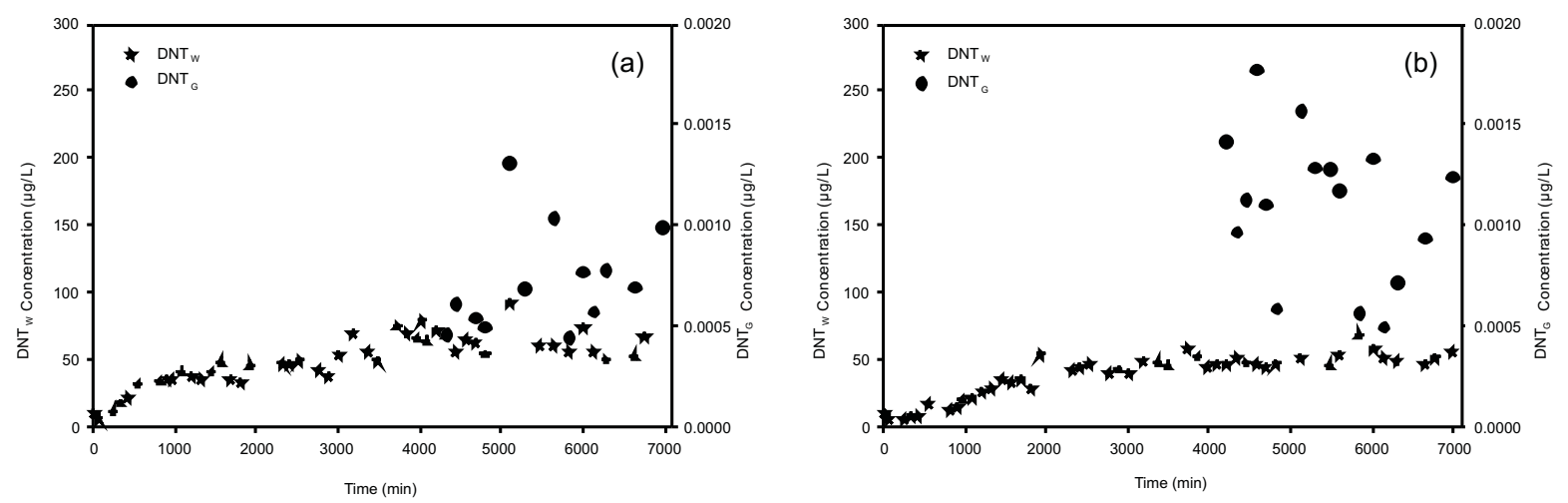

Figure 10. DNT $T_{W}$ vs. $D N T_{G}$ during infiltration process for Port 4 (a) and Port 3 (b) under $45 \%$ of saturation at $25^{\circ} \mathrm{C}$ (Exp 3)
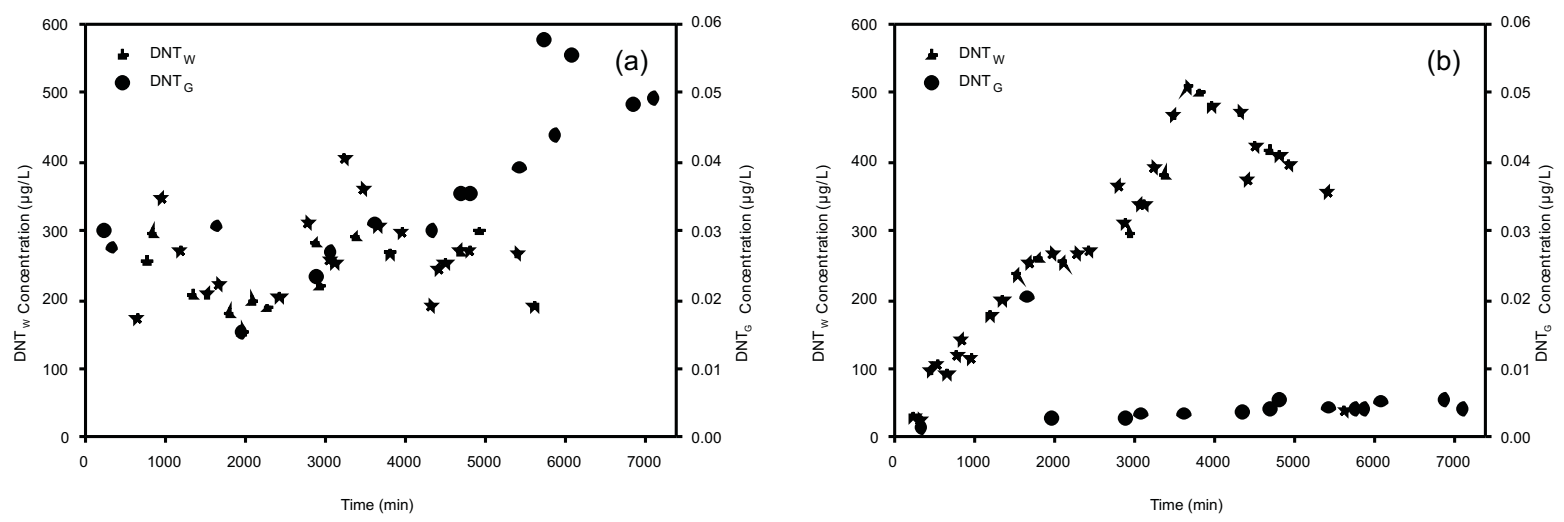

Figure 11. DNT $T_{W}$ vs. $D N T_{G}$ during infiltration process for Port 4 (a) and Port 3 (b) under $60 \%$ of saturation at $35^{\circ} \mathrm{C}$ (Exp 5)

Higher vapor concentrations at higher temperatures indicate greater volatilization at the higher temperature (Figures 10 and 11). No significant differences in temporal vapor concentrations are observed during infiltration periods because TNT and DNT are continuously dissolved through time. Decreasing temporal vapor-phase concentrations and redistribution, however, indicate vapor flux losses to the atmosphere.

Comparison of DNT vapor BTC in the soil near the soil surface and the soil surface (Figure 12) shows a very similar but temporally shifted behavior of vapor phase $\left(\mathrm{DNT}_{\mathrm{G}}\right)$ and aqueous $\left(\mathrm{DNT}_{\mathrm{w}}\right)$ concentrations. Vapor phase breakthrough lags that of the aqueous phase because it takes time for the buried source to pass through the soil from port 4 to port 5. Initial increase in vapor phase concentrations occurs from greater volatilization of the increasing aqueous concentration. Aqueous concentrations reach a peak value and then decrease as solutes are transferred to the vapor phase. The vapor phase concentration decreases after some time due to lower water concentrations and vapor diffusion transport. 


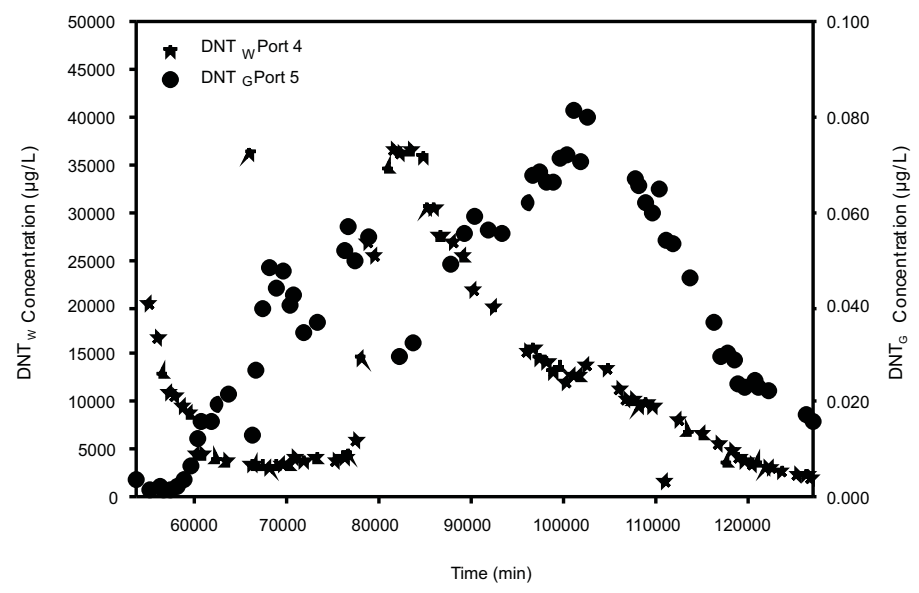

Figure 12. $D N T_{W}$ vs. $D N T_{G}$ breakthrough curves in the surface of the soil during evaporation process in the second stage of the experiment under saturated conditions at $35^{\circ} \mathrm{C}$ (Exp 4)

\section{Conclusions}

The downward movement of TNT and DNT with infiltrating water is generally retarded by sorption processes at soil and air-water surfaces.

The fate and transport of TNT and DNT in soils subjected to variable flow and water contents are influenced by dissolution (source-water), volatilization (water-air), and sorption (watersoil) mass transfer limitations.

TNT and DNT concentrations tend to initially decrease with time after infiltration periods. The decrease is attributed to slow dissolution of ERC source, and greater sorption and volatilization losses, and transformation/degradation processes.

Later upward movement of water during evaporation processes results in upward movement of solutes toward the soil-atmospheric surfaces. Water evaporation near the soil surface result in increased solute concentrations near the soil surface after prolonged evaporation periods.

TNT and DNT vapor concentrations indicate volatilization and gaseous transport during infiltration periods.

\section{Acknowledgments}

This research was supported by Army Research Office, DoD MURI Program, Grant No. DAAD
19-02-1-0257. The authors express their gratitude for financial, scientific and technical support provided DoD-ARO, Night Vision Laboratory and JUXOCO.

\section{References}

Brannon, J.M., Deliman, P., Ruiz, C., Price, C.B., Qasim, M., Gerald, J.A., Hayes, C., \& Yost, S. (1999). Conceptual model and process descriptor formulations for fate and transport of UXO. US Army Corps of Engineers, Waterways Experimental Station, Technical Report IRRP-99-1.

Comfort, S.D., Shea, P.J., Hundal, L.S., Li, Z., Woodbury, B.L., Martin, J.L., \& Powers, W.L. (1995). TNT transport and fate in contaminated soil. Journal of Environmental Quality 24(6), 11741182.

Costanza, M.S., \& Brusseau, M.L. (2002). Gas phase advection and dispersion in unsaturated porous media. Water Resources Research 38(4), 1036.

Fetter, C.W. (1999). Contaminant hydrogeology. New Jersey: Prentice Hall Inc.

Gutiérrez, J.P. (2008). Effects of flow reversal on two-dimensional transport of explosive chemicals in soils. Master Thesis, Department of Civil Engineering and Surveying, University of Puerto Rico, Mayaguez, Puerto Rico. 
Hoff, J.T., Gillham, R.W., Mackay, D., \& Shiu, W.Y. (1993). Sorption of organic vapors in a sand aquifer material. Environmental Science Technology 27(13), 2789-2794.

Jhorar, R.K., Bastiaanssen, W.G.M., Feddes, R.A., \& Van Dam, J.C. (2002). Inversely estimating soil hydraulic functions using evapotranspiration fluxes. Journal of Hydrology 258(1-4), 198-213.

Johnson, G.R., Gupta, K., Putz, D.K., Hu, K., \& Brusseau, M.L. (2002). The effect of local-scale physical heterogeneity and nonlinear, rate-limited sorption/desorption on contaminant transport in porous media. Journal of Contaminant Hydrology 64(1-2), 3558 .

Molina, G.I., Padilla, I., Pando, M., \& Pérez, D. (2006). Field lysimeters for the study of fate and transport of explosive chemical in soils under variable environmental conditions. In Proceedings in Detection and Remediation Technologies for Mines and Minelike Targets XI, SPIE Defense and Security Symposium, Orlando, USA, Vol. 6217.137.

Padilla, I.Y., Jim Yeh, T.C., \& Conklin, M.H. (1999). The effect of water content on solute transport in unsaturated porous media. Water Resources Research 35 (11), 33033313.

Padilla, A.C., Padilla, I.Y., \& Santiago, I. (2006). Multiphase extraction sampling of explosives in unsaturated soils. In Proceedings in Detection and Remediation Technologies for Mines and Minelike Targets XI. SPIE Defense and Security Symposium, Orlando, USA, Vol. 6217, 62173C, p. 1-11.

Phelan, J.M. \& Webb, S.W. (1998). Chemical detection of buried landmines. In Proceeding of the 3rd International Symposium on Technology and the Mine Problem, Mine Warfare Association.
Phelan, J.M. \& Barnett, J.L. (2001). Phase partitioning of TNT and DNT in soils. Sandia National Laboratories, Sand Report SAND20010310 .

Phelan, J.M., Gozdor, M., Webb, S.W., \& Cal, M. (2000). Laboratory data and model comparisons of the transport of chemical signatures from buried landmines/UXO. In Proceedings of the SPIE 14th Annual International Symposium on Aerospace/Defense Sensing, Simulation and Controls, Detection and Remediation Technologies for Mines and Minelike Targets V, Orlando, USA.

Roberson, J.A. \& Crowe, C.T. (1990). Engineering fluid mechanics. Houghton Mifflin Company, 4th Edition.

Rodríguez, S., Padilla, I. \& Santiago, I. (2006). Development of a multi-scale packing methodology for evaluating fate and transport processes of explosive-related chemicals in soil physical models. In Proceedings in Detection and Remediation Technologies for Mines and Minelike Targets XI, SPIE Defense and Security Symposium, Orlando, USA, Vol. 6217.62171U, p. 1-10.

Šimůnek, J., Šejna, M. \& van Genuchten, M.Th. (2005). The Hydrus 1-D software package for simulating the one-dimensional movement of water, heat, and multiple solutes in variably-saturated media. Version 3.0, HYDRUS Software Series 1, Department of Environmental Sciences, University of California Riverside, Riverside, California, USA.

Torres A., Padilla, I. \& Hwang, S. (2007). Physical modeling of 2,4-DNT gaseous diffusion through unsaturated soil. Proceedings of SPIE, Detection and Remediation Technologies for Mines and Minelike Targets XII, SPIE Defense and Security Symposium, Orlando, FL., April 9-13, 6553. 